\title{
Tuber 2013: scientific advances in sustainable truffle culture
}

\author{
Beatriz Águeda • Alessandra Zambonelli • Randy Molina
}

Received: 12 February 2014 / Accepted: 25 February 2014 / Published online: 11 March 2014

(C) Springer-Verlag Berlin Heidelberg 2014

Since the 3rd International Truffle Conference in Spoleto (2008), researchers have made considerable progress in advancing understanding of the biology and ecology of Tuber species and in improving the sustainable productivity of these valuable fungi. Publication of the black truffle, Tuber melanosporum Vittad., genome (Martin et al. 2010) has opened new possibilities to explore gene functions and population dynamics of black truffles. New molecular technologies provide valuable tools to monitor black truffle development (Parladé et al. 2013) and allow researchers and managers to monitor the success of new truffle plantations and the effects of cultivation treatments on truffle productivity.

Given the significant impact of truffle plantations on local economies, the regional government of Aragón, together with other institutes and truffle grower groups (see "Acknowledgments"), organized the 1st International Congress of Trufficulture in Teruel on March 5-8, 2013. The province of Teruel (Aragón region, Spain) produces almost $20 \%$ of the global truffle market and hosts $11 \%$ of the world's black truffle plantations. The main objective of the congress was to promote the sustainable productivity of truffles by highlighting and exchanging the latest scientific advances in truffle biology, ecology, and truffle plantation management among researchers, students, truffle hunters, truffle growers, forest managers, land-use planners, and rural

B. Águeda $(\bowtie)$

CITA, Centro de Investigación y Tecnología Agroalimentaria de Aragón, Avenida de Montañana 930, 50059 Zaragoza, Spain e-mail: beatrizagueda@yahoo.es

A. Zambonelli

Dipartimento di Scienze Agrarie, University of Bologna, via Fanin

46, 40127 Bologna, Italy

R. Molina

Department of Forest Ecosystems and Society, Oregon State

University, Corvallis, OR 97330, USA entrepreneurs from around the world. The conference brought together 270 participants from 23 countries of Europe, North and South America, Australia, and New Zealand.

More than 100 presentations, of which, 54 oral and the remaining posters, covered many aspects of truffle biology, genetics, taxonomy, ecology, cultivation, and commercialization. The congress also included market displays by regional truffle entrepreneurs and a local field trip to productive truffle plantations, seedling nurseries, and a truffle processing facility. Congress attendees thus experienced firsthand the many aspects of the region's practicing truffle culture. The trip culminated with a delightful banquet where all enjoyed the essence of truffle cuisine.

\section{Purpose and content of this special issue}

Congress organizers felt it was important to share the science findings with the international community and partnered with Springer to publish this special issue of Mycorrhiza. The published papers are not formal proceedings, but instead focus on presentations selected by the guest editors to highlight significant scientific findings that advance sustainable truffle culture. All abstracts and links to presentation videos are available at: www.tuber2013.com.

The first two papers review important findings on the diversity of ectomycorrhizal (ECM) fungi associated with truffle fungi and the reproductive biology of T. melanosporum. Truffle researchers and managers have long known that colonization of outplanted, truffle-inoculated seedlings by unwanted, competing ECM fungi impedes colonization by the targeted truffle species and can lower truffle production or lead to plantation failure. Yet, we lack a comprehensive understanding of ECM fungal dynamics in natural truffle sites and plantations. In this context, De Miguel et al. (2014) synthesize findings from 85 papers on truffle fungal communities around the world 
and provide insight on commonly occurring and likely competing ECM fungal species and on the influence of plantation age, host species, surrounding environment, and management practices on species composition. A new understanding of potential fungal species indicators of productive and nonproductive plantations emerges from this study. In the following paper, Rubini et al. (2014) provide a comprehensive overview of the life cycle of T. melanosporum that focuses on the heterothallic mating system and competition between the two mating types for ECM colonization of inoculated seedlings and mature plantation trees. Such competition can strongly influence mating type distribution in plantations, and when unbalanced, mating types cannot contact one another which can result in truffle production gaps within the plantation or even plantation failure. The authors note that new approaches in plant inoculation techniques and in agronomic practices are needed to balance mating type distribution and improve truffle production.

Improvement of sustainable truffle culture requires progress in two fundamental aspects of truffle science: (1) efficient detection of the presence, abundance, and spread of a targeted truffle fungus on inoculated seedlings and trees in plantations and (2) effects of various management practices on ECM development and truffle production. Seven research papers examine various aspects of these issues.

The use of well-colonized truffle seedlings, free of contaminant ECM fungi, is the first critical step in developing successful truffle plantations. Andrés-Alpuente et al. (2014) compare five methods used in Europe to evaluate successful T. melanosporum colonization of Quercus ilex L.-inoculated seedlings. The various methods differ in approach and evaluation time and can yield significant differences in evaluating final seedling quality. After reviewing the strengths and weaknesses of each approach, the authors emphasize the need for the truffle industry to reach consensus on the best method for certifying truffle seedlings.

Given the high investment costs for establishing truffle plantations, quick detection of truffle fungus persistence and spread in young plantations is needed to evaluate whether a newly established plantation is likely to succeed or fail. Sánchez et al. (2014) present an easy and reliable method to quickly check for the presence of $T$. melanosporum ectomycorrhiza on $Q$. ilex plantation trees and conclude that only three trees need sampling to provide a reasonable estimate of black truffle ectomycorrhiza presence. Liu et al. (2014) examine the rate of black truffle mycelial spread on $Q$. ilex plantation trees of different ages and report that mycelium extension reaches a maximum from the base of trees after 7 to 10 years. These findings address important questions regarding tree density in plantations and the potential for different dominant truffle mating types on individual trees to contact one another and initiate sporocarp formation.
High soil $\mathrm{pH}$ and liming practices are well-known to affect successful establishment of T. melanosporum in plantations, but less in known about soil physical factors affecting truffle fungus persistence, growth, and ascoma production. Alonso Ponce et al. (2014) hypothesize that various soil physical factors, together with cultivation techniques, significantly influence success or failure of T. melanosporum truffle production. By comparing soil factors under productive and nonproductive truffle trees, they report that low levels of fine earth and silt and high levels of bulk density, clay content, and water holding capacity promote truffle production. Moreover, they propose a logistic model based on soil variables that predicts whether a soil has a high or low probability to produce truffles. Such a model provides plantation owners with a quantitative tool to assess the risk in selecting sites for establishing new truffle plantations.

A thorough understanding of environmental conditions that trigger the initiation of truffle formation is lacking. By examining annual patterns of soil metabolic activity in T. melanosporum plantations, Pacioni et al. (2014) find that $\mathrm{CO}_{2}$ production is a reliable parameter to reflect development of truffle primordia. They also calibrate a ground-penetrating radar device to discriminate truffle primordia and follow primordial development into mature truffles. Such a technological advancement could improve prediction of truffle production long before dogs detect ripe truffles.

Soil moisture is critical for truffle production, and modern irrigation systems are commonly installed in truffle plantations, but how much irrigation and timing of irrigation remain outstanding questions. In a study of the effect of five irrigation regimes (from none to high) at three periods (spring-early summer, late summer-fall, spring-fall) on abundance of T. melanosporum ectomycorrhiza on truffle trees, Olivera et al. (2014) find that moderate irrigation in spring-early summer or late summer-fall promotes more truffle ectomycorrhiza than no irrigation or irrigation throughout the seasons. They emphasize that adequate soil moisture is needed in the early season, particularly in dry years, to promote root growth and ectomycorrhiza development as well as in the fall when the fungal sexual cycle is initiated.

Soil tillage is typically recommended in black truffle plantations to discourage weeds and stimulate truffle tree root growth, but similar information is lacking for the Italian white truffle, Tuber magnatum Pico which is only found in natural truffle sites and produces low numbers of difficult to detect ectomycorrhiza. Salerni et al. (2014) report the effects of shallow tilling in a natural white truffle site on the quantity of white truffle mycelium detected in soil by real-time PCR methods. Their observations indicate that tilling improves soil porosity and increases the quantity of white truffle mycelium, while decreasing the overall ECM fungal species diversity. Although it remains unknown whether cultivation practices can increase white truffle sporocarp production, real-time 
PCR could provide a reliable and easy method to detect fungal presence compared to sampling for infrequent white truffle ectomycorrhiza or sporocarps that vary in annual productivity.

Although the number of truffle plantations continues to grow worldwide, overall production of truffles has decreased over the last several decades, particularly in small natural truffle areas. Understanding and conserving the natural diversity within truffle populations is important to future truffle culture. García-Cunchillos et al. (2014) observe a high level of genetic diversity between two main groups separated by the Iberian mountain system when examining natural Spanish populations of T. melanosporum. They discuss the possibility that Spanish populations of T. melanosporum acted as a refuge during glaciation periods and later migrated to southwest France during post glaciation. In a phylogenetic analysis on specimens of Tuber brumale Vittad. collected across its range in 19 countries, Merényi et al. (2014) find that this species clusters into two large clades of morphologically cryptic species lineages. Prior glaciation and migration events likely contributed to this genetic structure.

The final paper, by Le Tacon et al. (2014), on understanding the decline of wild black truffle production in France was not presented at the congress, but was specially invited by the guest editors because of its relevance to truffle culture. Wild truffle production is nearly absent from forests of Italy and France, and such absence may occur in Spain if forest management practices continue to negatively impact on natural truffle sites. Le Tacon et al. (2014) calculate the quantity of truffles sold in wholesale markets in France over the last 25 years and find that production has remained remarkably stable. They conclude, however, that the long-term decline in black truffle production in France is more likely due to changes in truffle habitats in rural communities (e.g., decrease in land devoted to truffle culture and abandon of old truffle orchards) than to climatic changes.

\section{Concluding remarks}

The Teruel Truffle congress and this special issue of Mycorrhiza provide an important avenue to bridge the gap between truffle mycorrhizal science and its application in rural communities. The mystic of finding, producing, and eating truffles continues to flourish as truffle culture and access to marketed truffles expand worldwide. This interest and expansion comes at a time when rural economies are struggling with high unemployment and with securing sustainable agricultural income. Such is the case in the province of Teruel where many rural farmers have turned to truffle production to improve their livelihoods and build a sound future economy. Realizing this future needs continued input from the mycorrhiza scientific community to address outstanding questions regarding sustainable truffle culture.
Acknowledgments The 1st International Congress of Trufficulture of Teruel, Tuber 2013, was organized by the Industry and the Agriculture Department and the Centro de Investigación y Tecnología Agroalimentaria de Aragón (CITA) of the Aragón government. Collaborators included the Teruel City Council, Teruel Council, Huesca Council, Zaragoza Council, National Institute for Agricultural and Food Research and Technology (INIA, Spanish government), Aragón Development Institute, Dinópolis, Teruel Chamber of Commerce, Teruel Employers' Federation, Caja Rural of Teruel, Teruel Black Truffle Growers Federation (ATRUTER), Gúdar-Javalambre region, Spanish Truffle Growers Federation (FEET), University of Zaragoza, Polytechnic University of Valencia (UPV), Forestry Spanish Society (SECF), and Cesefor Foundation. The authors would like to thank all the members of the organizing committee for their invaluable work in the success of this event, especially Mr. José Vicente Lacasa Azlor and Dr. Juan J. Barriuso (CITA, Zaragoza, Spain), and also Dr. Santiago Reyna Domenech (Universitat Politècnica de València, Spain) who promoted its accomplishment. Publication of this special issue of Mycorrhiza has been financed by Centro de Investigación y Tecnología Agroalimentaria de Aragón (CITA), Gobierno de Aragón, Spain.

\section{References}

Alonso Ponce R, Ágreda T, Águeda B, Aldea J, Martínez-Peña F, Modrego MP (2014) Soil physical properties influence 'black truffle' fructification in plantations. Mycorrhiza. doi:10.1007/s00572014-0558-7

Andrés-Alpuente A, Sánchez S, Martín M, Aguirre J, Barriuso J (2014) Comparative analysis of different methods for evaluating evergreen oaks mycorrhized with black truffle. Mycorrhiza. doi:10.1007/ s00572-014-0563-x

De Miguel AM, Águeda B, Sánchez S, Parladé J (2014) Ectomycorrhizal fungus diversity and community structure with natural and cultivated truffle hosts: applying lessons learned to future truffle culture. Mycorrhiza. doi:10.1007/s00572-013-0554-3

García-Cunchillos I, Sánchez S, Barriuso JJ, Pérez-Collazos E (2014) Population genetics of the westernmost distribution of the glaciations-surviving black truffle Tuber melanosporum. Mycorrhiza. doi:10.1007/s00572-013-0540-9

Le Tacon F, Marçais B, Courvoisier M, Murat C, Becker M (2014) Climatic variations explain annual fluctuations in French Périgord black truffle wholesale markets but does not explain the decrease in black truffle production over the last 48 years. Mycorrhiza. doi:10. 1007/s00572-014-0568-5

Liu B, Fischer C, Bonet JA, Olivera A, Inchusta A, Colinas C (2014) Pattern of Tuber melanosporum extramatrical mycelium expansion over a 20-year chronosequence in Quercus ilex-truffle orchards. Mycorrhiza. doi:10.1007/s00572-014-0559-6

Martin F, Kohler A, Murat C, Balestrini R, Coutinho PM, Jaillon O, Montanini B, Morin E, Noel B, Percudani R, Porcel B, Rubini A, Amicucci A, Amselem J, Anthouard V, Arcioni S, Artiguenave F, Aury JM, Ballario P, Bolchi A, Brenna A, Brun A, Buée M, Cantarel B, Chevalier G, Couloux A, Da Silva C, Denoeud F, Duplessis S, Ghignone S, Hilselberger B, Iotti M, Marçais B, Mello A, Miranda M, Pacioni G, Quesneville H, Riccioni C, Ruotolo R, Splivallo R, Stocchi V, Tisserrant E, Viscomi AR, Zambonelli A, Zampieri E, Henrissat B, Lebrun MH, Paolocci F, Bonfante P, Ottonello S, Wincker P (2010) Périgord black truffle genome uncovers evolutionary origins and mechanisms of symbiosis. Nature 464:10331038. doi: $10.1038 /$ nature 08867

Merényi Z, Varga T, Geml J, Orczán Ákos K, Chevalier G, Bratek Z (2014) Phylogeny and phylogeography of Tuber brumale aggr. Mycorrhiza (this special issue). doi:10.1007/s00572-014-0566-7 
Olivera A, Bonet JA, Oliach D, Colinas C (2014) Time and dose of irrigation impact Tuber melanosporum ectomycorrhiza proliferation and growth of Quercus ilex seedling hosts in young black truffle orchards. Mycorrhiza. doi:10.1007/s00572-013-0545-4

Pacioni G, Leonardi M, Di Carlo P, Ranalli D, Zinni A, De Laurentiis G (2014) Instrumental monitoring of the birth and development of truffles in a Tuber melanosporum orchard. Mycorrhiza. doi:10. 1007/s00572-014-0561-z

Parladé J, De la Varga H, De Miguel AM, Sáez R, Pera J (2013) Quantification of extraradical mycelium of Tuber melanosporum in soils from truffle orchards in northern Spain. Mycorrhiza 23: 99-106
Rubini A, Riccioni C, Belfiori B, Paolocci F (2014) Impact of the competition between mating types on the cultivation of Tuber melanosporum: Romeo and Juliet and the matter of space and time. Mycorrhiza. doi:10.1007/s00572-013-0551-6

Salerni E, Iotti M, Leonardi P, Gardin L, D'Aguanno N, Perini C, Pacioni G, Zambonelli A (2014) Effects of soil tillage on Tuber magnatum development in natural truffières. Mycorrhiza. doi:10.1007/s00572013-0543-6

Sánchez S, Ágreda T, Águeda B, Martín M, de Miguel AM, Barriuso J (2014) Persistence and detection of black truffle ectomycorrhizas in plantations: comparison between two field detection methods. Mycorrhiza. doi:10.1007/s00572-014-0560-0 